\title{
Salbutamol nebulization for management of transient tachypnea of newborn (TTN).
}

\footnotetext{
1. MBBS, FCPS (Paeds Medicine) Senior Registrar Pediatrics Shifa Tameer e Millat University Islamabad.

2. MBBS, FCPS (Paeds Medicine) Assistant Professor Pediatric Emergency

Mayo Hospital, Lahore.

3. MBBS, FCPS (Paeds)

Assistant Professor Pediatric Medicine

Gujranwala Medical College, Gujranwala.

4. MBBS, FCPS

Assistant Professor Pediatrics Services Institute of Medical Sciences, Lahore.

5. MBBS, FCPS (Paeds)

Neonatologist Pediatric Medicine

Federal Government Services Hospital Islamabad.

6. MBBS, FCPS (Paeds) Assistant Professor Pediatric Medicine

King Edward Medical University Lahore.

7. MBBS, PGPN

Medical Officer Paediatrics

General Hospital, Faisalabad.
}

Correspondence Address:

Dr. Muhammad Ahsan

Medical Officer Paediatrics

General Hospital, Faisalabad.

ahsanjahangir194@gmail.com

Article received on:

05/03/2020

Accepted for publication:

23/06/2020

\section{INTRODUCTION}

Transient Tachypnea of the new born (T.T.N) is a parenchymal disorder of the lung in which pulmonary oedema occurs after delayed clearance of foetal fluid of the alveoli. ${ }^{1}$ T.T.N is one of the causes of respiratory distress in the neonatal period. The incidence of T.T.N is about 6 in 1000 live births. Normally, there is decrease in the foetal lung liquid in the antenatal period leading to shift of fluid into the interstitium. This process is complete in most normal neonates within several hours after birth. Tachypnea occurs when foetal lung fluid is not adequately or rapidly cleared, for various reasons. ${ }^{2}$

Stimulation of the tissues of the feotal lung by
Fatima Maroof ${ }^{1}$, Tehmina Maqbool ${ }^{2}$, Hafiz Muhammad Irfan ${ }^{3}$, Beenish Bashir Mughal ${ }^{4}$, Aisha Anwar ${ }^{5}$, Nabeela Zia ${ }^{6}$, Muhammad Ahsan ${ }^{7}$

ABSTRACT... Objective: To compare the mean change in respiratory rate with salbutamo (PGMI), Islamabad. Period: $8^{\text {th }}$ August 2017 to $7^{\text {th }}$ February 2018. Material \& Methods: 100 group were nebulized with Salbutamol. Placeb Then neonates were followed-up in N.I.C.U after 4 hours of second nebulization. After 4 hours, respiratory rates were assessed and change in respiratory rate was noted. Both groups were rate was changed from $81.88 \pm 8.86 \mathrm{bpm}$ to $62.50 \pm 6.75 \mathrm{bpm}$. This was significant decrease $\mathrm{p}<0.05)$. The difference between both groups at baseline was insignificant while after 4 (edion salbutamol can be helpful in reducing respiratory rate significantly in neonates with TTN as

Key words: $\quad$ Placebo, Reduction in Respiratory Rate, Salbutamol Nebulization, Transient Tachypnea of New-Born.

Article Citation: Maroof F, Maqbool T, Irfan HM, Mughal BB, Anwar A, Zia N, Ahsan M. Salbutamol nebulization for management of transient tachypnea of newborn (TTN). Professional Med J 2021; 28(1):52-59. https://doi.org/10.29309/TPMJ/2021.28.01.4614

exo-genous $\beta$ - adrenergics lead to lung fluid absorption both in the human and animal. ${ }^{3-5}$ Various studies at different age groups done on the lung physiology of fluid clearance show that Salbutamol helps in clearance of lung fluid. ${ }^{6}$

A study was conducted in India which showed that there is significant decrease in mean respiratory rate in neonates who received Salbutamol nebulization $(9.43 \pm 1.48 \mathrm{bpm})$ as compared to placebo group $(3.6 \pm 0.21 \mathrm{bpm})$, the difference is statistically significant with the $(P=0.004) .{ }^{7}$ But another study showed that there were insignificant difference in respiratory rate $(P>0.05)$ whether Salbutamol nebulization given or not. ${ }^{8}$ 
The rationale of this study is to compare the mean reduction in respiratory rate with salbutamol nebulization versus placebo for treatment of TTN. As TTN is a common cause of hospitalization in NICU, a treatment option which can be helpful in decreasing the duration and severity of tacyopnea merits further evaluation. This modality being a cheap intervention has an enormous potential for cost saving, both in developing and developed countries, because it can actually reduce length of hospitalization. Thus, not only will it significantly reduce the hospital economy burden but will also prevent the incidence of hospital acquired infection among neonates and associated anxiety among parents. Literature has showed that salbutamol is more effective in reducing excessive respiratory rate in neonates with tachypnea. But controversial evidence has been noticed in literature. Moreover, no local evidence has been found in literature. We want to conduct this study to confirm the beneficial role of salbutamol. So, that we may be able to implement the results in local settings.

\section{MATERIAL \& METHODS}

This randomized control trial was done at the Neonatology Department, Federal Government Polyclinic (PGMI), Islamabad, in six months after the approval of the synopsis i.e. from $8^{\text {th }}$ August 2017 to $7^{\text {th }}$ February 2018. Objective of the study was to compare the mean change in respiratory rate with salbutamol nebulization versus placebo for treatment of transient tacyopnea of newborn. Alternate Hypothesis for this study was that there is a difference in mean change in respiratory rate with salbutamol nebulization versus placebo for treatment of TTN. Transient Tacyopnea of Newborn was defined as neonates presenting with Respiratory Rate $>60$ breaths/min within 6 hours after birth, respiratory distress of $<6$ hours after birth and Silverman-Anderson score of $>5$
(T.T.N score). Change in respiratory rate was measured as change in respiratory rate after 4 hours of nebulization in terms of breaths per minute.

\section{TTN scoring system}

100 cases were collected using non-probability consecutive sampling (50 cases in each group) Sample size was calculated using WHO sample size calculator taking Confidence Interval: 95\%, Power of test: $80 \%$ and expected magnitude of mean reduction in respiratory rate i.e. $9.43 \pm 1.48 \mathrm{bpm}$ with salbutamol and $3.6 \pm 0.21 \mathrm{bpm}$ with placebo for TTN.

All neonates born of either genders at gestational age $>37$ weeks (accessed on antenatal record) meeting the operational deflation of Transient Tachypnea of Newborn were included in the study. While patients with meconium aspiration syndrome (on history), neonatal respiratory distress syndrome (on medical record), Neonates with medical record of Congenital Heart Disease, Congenital Pneumonia, Persistent Pulmonary Hypertension, Early Onset Neonatal Sepsis/DIC, Hypoglycaemia were excluded from the study.

Demographic information (name, age, sex, birth weight) was also noted. All baseline respiratory rates were noted. Neonates were divided into two groups by lottery method. Neonates in Treatment group were nebulized with Salbutamol at dose of $0.15 \mathrm{mg} / \mathrm{kg} / \mathrm{dose}$ in $2 \mathrm{ml}$ of $0.9 \%$ Normal Saline over duration of 10 minutes. Placebo group was nebulized with $2 \mathrm{ml}$ of $0.9 \%$ Normal Saline. A total of two nebulization was done with an interval of 4 hours between both nebulizations. Both the groups were provided with standard therapy as per N.I.C.U protocol i.e. Oxygen inhalation, intravenous fluids and intravenous antibiotics.

\begin{tabular}{|l|c|c|c|c|}
\hline \multicolumn{1}{|c|}{ Score } & 0 Point & 1 Point & 2 Points \\
\hline Expiratory Grunting & None & Intermittent & Continuous \\
\hline Supraclavicular Retraction & None & Mild & Moderate & Severe \\
\hline Subcostal Retraction & None & Mild & Moderate & Severe \\
\hline Cyanosis & None & At Extremities & Central & - \\
\hline Nasal Flaring & None & Mild & Moderate & Severe \\
\hline
\end{tabular}


Then neonates were followed-up after 4 hours of second nebulization. After 4 hours, respiratory rate was assessed and change in respiratory rate was noted (as per operational definition).

Data was entered and analysed using SPSS 21.0. Frequency and percentages for qualitative variables like gender, and mean with SD for quantitative variables like gestational age, birth weight, respiratory rate at baseline and after 4 hours and change in respiratory rate was calculated. Both groups were compared for mean change in respiratory rate by using independent sample t-test. P-value $\leq 0.05$ was taken as significant. Confounder e.g. Gender, Weight, Gestation at birth, Hours of life, were controlled through stratification. Post stratification independent sample t-test was applied and $P$ $\leq 0.05$ was taken as significant.

\section{RESULTS}

In this study, the mean age of neonates in nebulized salbutamol group was $3.26 \pm 1.59$ hours and the mean age of neonates in placebo group was $3.14 \pm 1.68$ hours. There were $26(52.0 \%)$ male and $24(48.0 \%)$ female neonates in nebulized salbutamol group and there were 26 (52.0\%) male and 24 (48.0\%) female neonates in placebo group. The mean weight of neonates in study with nebulized salbutamol group was 2963.36 \pm 282.79 grams and the mean weight of neonates in placebo group was $3034.86 \pm 273.64$ grams. In this study, the mean gestational age of neonates was $39.90 \pm 1.43$ weeks in nebulized salbutamol group and the mean gestational age of neonates in placebo group was $40.00 \pm 1.46$ week.

At baseline, the mean respiratory rate of neonates in nebulized salbutamol group was $79.62 \pm 8.18 \mathrm{bpm}$ and the mean respiratory rate of neonates in placebo group was $81.88 \pm 8.86 \mathrm{bpm}$. The difference was insignificant $(p>0.05)$. Table-I

After 4 hours of treatment, the mean respiratory rate of neonates in nebulized salbutamol group was $52.06 \pm 4.96 \mathrm{bpm}$ and the mean respiratory rate of neonates in placebo group was $62.50 \pm 6.75 \mathrm{bpm}$. The difference was significant $(p<0.05)$. Table-II
The mean respiratory rate of all neonates, included in this study, at baseline was $80.75 \pm 8.56 \mathrm{bpm}$ which was changed to $57.28 \pm 7.89 \mathrm{bpm}$. There was significant reduction in respiratory rate $(p<0.05)$. Table-III

In nebulized salbutamol, group, mean respiratory rate was changed from $79.62 \pm 8.18 \mathrm{bpm}$ to $52.06 \pm 4.96 \mathrm{bpm}$. This was significant decrease $(p<0.05)$. In placebo group, mean respiratory rate was changed from $81.88 \pm 8.86 \mathrm{bpm}$ to $62.50 \pm 6.75 \mathrm{bpm}$. This was significant decrease $(p<0.05)$. The difference between both groups at baseline was insignificant while after 4 hours was significant. Table-IV

The mean reduction in respiratory rate with nebulized salbutamol was $27.56 \pm 6.83 \mathrm{bpm}$ while with placebo was $19.35 \pm 9.83 \mathrm{bpm}$. There was significant difference in mean change in respiratory rate $(p<0.05)$. Table- $V$

Data was stratified for age of neonates. Among neonates 1-3hours old, mean reduction in respiratory rate was $27.07 \pm 7.29 \mathrm{bpm}$ with nebulized salbutamol and $18.90 \pm 9.78 \mathrm{bpm}$ with placebo. Among neonates 4-6hours old, mean change in respiratory rate was $28.24 \pm 6.24 \mathrm{bpm}$ with nebulized salbutamol and $20.16 \pm 10.12 \mathrm{bpm}$ with placebo. The difference was significant between both groups in each strata $(p<0.05)$. Table-VI

Data was stratified for gender of neonates. Among male neonates, mean change in respiratory rate was $27.46 \pm 6.81 \mathrm{bpm}$ with nebulized salbutamol and $17.62 \pm 9.25 \mathrm{bpm}$ with placebo. Among female neonates, mean changed in respiratory rate was $27.67 \pm 6.99 \mathrm{bpm}$ with nebulized salbutamol and $21.29 \pm 10.27 \mathrm{bpm}$ with placebo. The difference was significant between both groups in each strata $(p<0.05)$. Table-VII

Data was stratified for birth weight of neonates. Among neonates with 2500-3000grams weight, mean change in respiratory rate was $28.18 \pm 6.90 \mathrm{bpm}$ with nebulized salbutamol and $19.71 \pm 9.93 \mathrm{bpm}$ with placebo. Among neonates with 3100-3500 grams weight, mean changed 
in respiratory rate was $26.77 \pm 6.80 \mathrm{bpm}$ with nebulized salbutamol and $19.14 \pm 9.92 \mathrm{bpm}$ with placebo. The difference was significant between both groups in each strata $(p<0.05)$. Table-VIII

Data was stratified for gestational age at birth. Among neonates born at 38-40weeks, mean change in respiratory rate was $27.81 \pm 7.01 \mathrm{bpm}$ with nebulized salbutamol and 18.26 $\pm 10.53 \mathrm{bpm}$ with placebo. Among neonates with born at 40-41weeks, mean change in respiratory rate was $27.11 \pm 6.66 \mathrm{bpm}$ with nebulized salbutamol and $20.70 \pm 8.98 \mathrm{bpm}$ with placebo. The difference was significant between both groups in each strata $(p<0.05)$. Table-IX

A Comparison of All variables between Nebulized Salbutamol group and Placebo Group is shown in Table-X.

\begin{tabular}{|c|c|c|c|}
\hline & & \multicolumn{2}{|c|}{ Group } \\
\hline & & $\begin{array}{l}\text { Nebulized } \\
\text { Salbutamol }\end{array}$ & Placebo \\
\hline \multirow{3}{*}{$\begin{array}{l}\text { Respiratory } \\
\text { Rate (bpm) }\end{array}$} & $\mathrm{N}$ & 50 & 50 \\
\hline & Mean & 79.62 & 81.88 \\
\hline & SD & 8.18 & 8.86 \\
\hline \multicolumn{4}{|c|}{$\begin{array}{c}\text { Table-I. Comparison of respiratory rate (bpm) at } \\
\text { baseline in both groups } \\
\text { Independent samples t-test }=1.325, \text { p-value } 0.188 \\
\text { (Insignificant) }\end{array}$} \\
\hline
\end{tabular}

\begin{tabular}{|c|c|c|c|}
\hline & & \multicolumn{2}{|c|}{ Group } \\
\hline & & $\begin{array}{l}\text { Nebulized } \\
\text { Salbutamol }\end{array}$ & Placebo \\
\hline \multirow{3}{*}{$\begin{array}{l}\text { Respiratory } \\
\text { Rate (bpm) }\end{array}$} & $\mathrm{N}$ & 50 & 50 \\
\hline & Mean & 52.06 & 62.50 \\
\hline & SD & 4.96 & 6.75 \\
\hline \multicolumn{4}{|c|}{$\begin{array}{l}\text { Table-II. Comparison of respiratory rate (bpm) at } \\
\text { 4hours in both groups } \\
\text { Independent samples t-test }=8.809, \text { p-value } 0.000 \\
\text { (Significant) }\end{array}$} \\
\hline & & \multicolumn{2}{|c|}{ Follow-up } \\
\hline & & Baseline & After 4 Hours \\
\hline \multirow{3}{*}{$\begin{array}{l}\text { Respiratory } \\
\text { Rate (bpm) }\end{array}$} & $\mathrm{N}$ & 50 & 50 \\
\hline & Mean & 80.75 & 57.28 \\
\hline & SD & 8.56 & 7.89 \\
\hline \multicolumn{4}{|c|}{$\begin{array}{l}\text { Table-III. Comparison of respiratory rate }(\mathrm{bpm}) \text { at } \\
\text { follow-up } \\
\text { Paired sample t-test }=25.055 ; \mathrm{p} \text {-value } 0.000 \\
\text { (Significant) }\end{array}$} \\
\hline
\end{tabular}

\begin{tabular}{|c|c|c|c|c|}
\hline & & \multicolumn{2}{|c|}{ Group } & \multirow{2}{*}{$\begin{array}{c}\text { P-Value (Independent } \\
\text { Samples) }\end{array}$} \\
\hline & & Nebulized Salbutamol & Placebo & \\
\hline \multirow{2}{*}{$\begin{array}{l}\text { Respiratory Rate } \\
\text { (bpm) }\end{array}$} & $\mathrm{N}$ & 50 & 50 & \\
\hline & After 4hours & $52.06 \pm 4.96$ & $62.50 \pm 6.75$ & 0.000 \\
\hline \multicolumn{2}{|c|}{ p-value (paired sample) } & 0.000 & 0.000 & \\
\hline
\end{tabular}

Table-IV. Comparison of respiratory rate (bpm) at follow-up in both groups

\begin{tabular}{|l|l|c|c|}
\hline \multicolumn{2}{|c|}{} & \multicolumn{2}{c}{ Group } \\
\hline \multirow{3}{*}{ Change } & N & Nebulized Salbutamol & 50 \\
\cline { 2 - 3 } & Mean & 27.56 & 19.38 \\
\cline { 2 - 3 } & SD & 6.83 & 9.83 \\
\cline { 2 - 3 } & Table-V. Comparison of change in respiratory rate in both groups \\
& Independent samples t-test = 4.834; p-value $\mathbf{0 . 0 0 0}$ (Significant)
\end{tabular}




\begin{tabular}{|c|c|c|c|c|}
\hline \multirow{2}{*}{ Age (hours) } & \multirow{2}{*}{ Change } & \multicolumn{2}{|c|}{ Group } & \multirow{2}{*}{ P-Value } \\
\hline & & Nebulized Salbutamol & Placebo & \\
\hline \multirow{2}{*}{$1-3$} & $\mathrm{~N}$ & 29 & 31 & \multirow{2}{*}{0.001} \\
\hline & Mean \pm SD & $27.07 \pm 7.29$ & $18.90 \pm 9.78$ & \\
\hline \multirow{2}{*}{$4-6$} & $\mathrm{~N}$ & 21 & 19 & \multirow{2}{*}{0.004} \\
\hline & Mean \pm SD & $28.24 \pm 6.24$ & $20.16 \pm 10.12$ & \\
\hline
\end{tabular}

\begin{tabular}{|c|c|c|c|c|}
\hline \multirow{2}{*}{ Gender } & \multirow{2}{*}{ Change } & \multicolumn{2}{|c|}{ Group } & \multirow{2}{*}{ P-Value } \\
\hline & & Nebulized Salbutamol & Placebo & \\
\hline \multirow{2}{*}{ Male } & $\mathrm{N}$ & 26 & 26 & \multirow{2}{*}{0.000} \\
\hline & Mean \pm SD & $27.46 \pm 6.81$ & $17.62 \pm 9.25$ & \\
\hline \multirow{2}{*}{ Female } & $\mathrm{N}$ & 24 & 24 & \multirow{2}{*}{0.015} \\
\hline & Mean \pm SD & $27.67 \pm 6.99$ & $21.29 \pm 10.27$ & \\
\hline
\end{tabular}

Table-VII. Comparison of change in respiratory rate in both groups stratified for gender

\begin{tabular}{|c|c|c|c|c|}
\hline \multirow{2}{*}{ Weight (Grams) } & \multirow{2}{*}{ Change } & \multicolumn{2}{|c|}{ Group } & \multirow{2}{*}{ P-Value } \\
\hline & & Nebulized Salbutamol & Placebo & \\
\hline \multirow{2}{*}{$2500-3000$} & $\mathrm{~N}$ & 28 & 21 & \multirow{2}{*}{0.001} \\
\hline & Mean $\pm S D$ & $28.18 \pm 6.90$ & $19.71 \pm 9.93$ & \\
\hline \multirow{2}{*}{$3100-3500$} & $\mathrm{~N}$ & 22 & 29 & \multirow{2}{*}{0.002} \\
\hline & Mean $\pm S D$ & $26.77 \pm 6.80$ & $19.14 \pm 9.92$ & \\
\hline
\end{tabular}

\begin{tabular}{|c|c|c|c|c|}
\hline \multirow{2}{*}{ Gestation (Weeks) } & \multirow{2}{*}{ Change } & \multicolumn{2}{|c|}{ Group } & \multirow{2}{*}{ P-Value } \\
\hline & & Nebulized Salbutamol & Placebo & \\
\hline \multirow{2}{*}{$38-40$} & $\mathrm{~N}$ & 32 & 27 & \multirow{2}{*}{0.000} \\
\hline & Mean $\pm S D$ & $27.81 \pm 7.01$ & $18.26 \pm 10.53$ & \\
\hline \multirow{2}{*}{$41-42$} & $\mathrm{~N}$ & 18 & 23 & \multirow{2}{*}{0.015} \\
\hline & Mean $\pm S D$ & $27.11 \pm 6.66$ & $20.70 \pm 8.98$ & \\
\hline
\end{tabular}

Table-IX. Comparison of change in respiratory rate in both groups stratified for gestational age

\begin{tabular}{|c|c|c|}
\hline & Salbutamol Group & Normal Saline Group \\
\hline No. of patients $\mathrm{n}(\%)$ & 50 & 50 \\
\hline Age (hours of life) & 3.26 hours & 3.14 hours \\
\hline $\begin{array}{l}\text { Gender } \\
\text { Male } \\
\text { Female }\end{array}$ & $\begin{array}{l}26(52.0 \%) \\
24(48.0 \%)\end{array}$ & $\begin{array}{l}26(52.0 \%) \\
24(48.0 \%)\end{array}$ \\
\hline Gestational Age (weeks) (mean \pm SD) & $39.90 \pm 1.4$ wks & $40.00 \pm 1.4 \mathrm{wks}$ \\
\hline Birth weight in kgs (mean $\pm S D)$ & $2.9 \pm 0.2$ & $3.0 \pm 0.2$ \\
\hline Respiratory Rate / Baseline Respiratory Rate at admission (mean \pm SD) & $79.62 \pm 8.18$ & $81.88 \pm 8.86$ \\
\hline Respiratory Rate / Respiratory Rate at 4 hours & $52.06 \pm 4.96$ & $62.50 \pm 6.75$ \\
\hline Comparison of Reduction in Respiratory Rate & $27.56 \pm 6.83$ & $19.38 \pm 9.83$ \\
\hline
\end{tabular}




\section{DISCUSSION}

TTN shows increasing incidence with increase in caesarean sections for maternal ease and the anxiety with the changing life-style. It is supposed to be due to result from delayed fluid resorption from the neonatal lungs, an important diagnostic dilemma in NICU. ${ }^{9}$

In our trial, the mean respiratory rate of neonates at baseline was $80.75 \pm 8.56 \mathrm{bpm}$ which was reduced to $57.28 \pm 7.89 \mathrm{bpm}$. There was a significant change in respiratory rate $(p<0.05)$. In nebulized salbutamol group, the mean respiratory rate was changed from $79.62 \pm 8.18 \mathrm{bpm}$ to $52.06 \pm 4.96 \mathrm{bpm}$. This was significant decrease $(p<0.05)$. In placebo group, mean respiratory rate was changed from $81.88 \pm 8.86 \mathrm{bpm}$ to $62.50 \pm 6.75 \mathrm{bpm}$. This was a significant decrease $(p<0.05)$. The difference between both groups at baseline was insignificant while after 4 hours was significant. Thus the mean change in terms of reduction in respiratory rate with nebulized salbutamol was $27.56 \pm 6.83 \mathrm{bpm}$ while with placebo was $19.35 \pm 9.83 \mathrm{bpm}$. There was significant difference in mean reduction in respiratory rate $(p<0.05)$.

A study was conducted in India which showed that there is significant decrease in mean respiratory rate in neonates who received Salbutamol nebulization $(9.43 \pm 1.48 \mathrm{bpm})$ as compared to placebo group $(3.6 \pm 0.21 \mathrm{bpm})$, the difference is statistically significant with the $(P=0.004) .{ }^{7}$ But another study showed that there were insignificant difference in respiratory rate $(P>0.05)$ whether Salbutamol nebulization given or not. ${ }^{8}$

A review was conducted, including 140 infants comparing nebulized salbutamol with placebo; one of three trials had newborns into two different doses of the intervention. We found differences in oxygen therapy duration but no differences in need for CPAP) or for mechanical ventilation. Among the secondary outcomes of these studies, there was no difference in terms of duration of hospital stay and tachypnea. It was concluded in this met analysis that currently there is insufficient evidence regarding the efficacy and safety of salbutamol in management of TTN.
This was because of paucity of included trials, small sample size. ${ }^{10}$ Not much has been done in literature. And our study also supported the nebulized salbutamol for TTN.

In this study, the mean age of neonates in nebulized salbutamol group was $3.26 \pm 1.59$ hours and the mean age of neonates in placebo group was $3.14 \pm 1.68$ hours. Data was stratified for age of neonates. Among neonates 1-3hours old, mean reduction in respiratory rate was $27.07 \pm 7.29 \mathrm{bpm}$ with nebulized salbutamol and $18.90 \pm 9.78 \mathrm{bpm}$ with placebo. Among neonates 4-6hours old, mean reduction in respiratory rate was $28.24 \pm 6.24 \mathrm{bpm}$ with nebulized salbutamol and $20.16 \pm 10.12 \mathrm{bpm}$ with placebo. The difference was significant between both groups in each strata $(p<0.05)$. Table-X

In study, we had 26 (52.0\%) male and 24 (48.0\%) female neonates in nebulized salbutamol group and there were $26(52.0 \%)$ male and 24 (48.0\%) female neonates in placebo group. Data was stratified for gender of neonates. Among male neonates, mean reduction in respiratory rate was $27.46 \pm 6.81 \mathrm{bpm}$ with nebulized salbutamol and $17.62 \pm 9.25 \mathrm{bpm}$ with placebo. Among female neonates, mean reduction in respiratory rate was $27.67 \pm 6.99 \mathrm{bpm}$ with nebulized salbutamol and $21.29 \pm 10.27 \mathrm{bpm}$ with placebo. The difference was significant between both groups in each strata $(p<0.05)$.

In this study, the mean weight of neonates in nebulized salbutamol group was $2963.36 \pm 282.79$ grams and the mean weight of neonates in placebo group was $3034.86 \pm 273.64$ grams. Data was stratified for birth weight of neonates. Among neonates with 2500-3000grams weight, mean reduction in respiratory rate was $28.18 \pm 6.90 \mathrm{bpm}$ with nebulized salbutamol and $19.71 \pm 9.93 \mathrm{bpm}$ with placebo. Among neonates with 3001-350grams weight, mean reduction in respiratory rate was $26.77 \pm 6.80 \mathrm{bpm}$ with nebulized salbutamol and $19.14 \pm 9.92 \mathrm{bpm}$ with placebo. The difference was significant between both groups in each strata $(p<0.05)$. 
The mean gestational age of neonates in nebulized salbutamol group was $39.90 \pm 1.43$ weeks in this study and the mean gestational age of neonates in placebo group was $40.00 \pm 1.46$ week. Data was stratified for gestational age at birth. Among neonates born at 38-40weeks, mean reduction in respiratory rate was $27.81 \pm 7.01 \mathrm{bpm}$ with nebulized salbutamol and $18.26 \pm 10.53 \mathrm{bpm}$ with placebo. Among neonates with born at 40-41weeks, mean change in respiratory rate was $27.11 \pm 6.66 \mathrm{bpm}$ with nebulized salbutamol and $20.70 \pm 8.98 \mathrm{bpm}$ with placebo. The difference was significant between both groups in each strata $(p<0.05)$.

\section{CONCLUSION}

It has been proved that nebulized salbutamol can be helpful in changing and reducing respiratory rate significantly in neonates with TTN as compared to placebo. Now the controversy resolved and salbutamol found to be effective in controlling respiratory rate of neonates. And we have also got local evidence. Now we will implement the nebulized salbutamol for neonates presenting with TTN in local setting.

Copyright $\subset 23$ June, 2020.

\section{REFERENCES}

1. Avery ME, Gatewood OB, Brumley G. Transient tachypnea of the newborn. Am J Dis Child 1966; 111(4):380-5.

2. Morrison JJ, Rennie JM, Milton PJ. Neonatal respiratory morbidity and mode of delivery at term: Influence of timing of elective caesarean section. BJOG: An International Journal of Obstetrics \& Gynaecology 1995; 102(2):101-6.
3. Sakuma T, Tuchihara C, Ishigaki M, Osanai K, Nambu Y, Toga $\mathrm{H}$, et al. Denopamine, a $\boldsymbol{\beta} 1$-adrenergic agonist, increases alveolar fluid clearance in ex vivo rat and guinea pig lungs. Journal of Applied Physiology 2001; 90(1):10-6.

4. Sakuma T, Folkesson H, Suzuki S, Okaniwa G, Fujimura $S$, Matthay MA. Beta-adrenergic agonist stimulated alveolar fluid clearance in ex vivo human and rat lungs. American journal of respiratory and critical care medicine 1997; 155(2):506-12.

5. Mutlu GM, Factor P. Alveolar epithelial $\beta 2$-adrenergic receptors. American journal of respiratory cell and molecular biology 2008; 38(2):127-34.

6. McAuley DF, Frank JA, Fang X, Matthay MA. Clinically relevant concentrations of $\beta 2$-adrenergic agonists stimulate maximal cyclic adenosine monophosphatedependent airspace fluid clearance and decrease pulmonary edema in experimental acid-induced lung injury. Critical care medicine 2004; 32(7):1470-6.

7. Kaur A, Kahlon PS, Singh K, Pannu M. Effect of salbutamol nebulization in transient tachypnea of newborn. Int J Curr Res Med Sci 2017; 3(8):1-7.

8. Kim M-J, Yoo J-H, Jung J-A, Byun S-Y. The effects of inhaled albuterol in transient tachypnea of the newborn. Allergy, asthma \& immunology research 2014; 6(2):126-30.

9. O'Brodovich H, Yang P, Gandhi S, Otulakowski G. Amiloride-insensitive $\mathrm{Na}+$ and fluid absorption in the mammalian distal lung. American Journal of Physiology-Lung Cellular and Molecular Physiology 2008;294(3):L401-L8.

10. Moresco L, Bruschettini M, Cohen A, Gaiero A, Calevo MG. Salbutamol for transient tachypnea of the newborn. status and date: New, published in 2015(9). 


\section{AUTHORSHIP AND CONTRIBUTION DECLARATION}

\begin{tabular}{|c|c|c|c|}
\hline Sr. \# & Author(s) Full Name & Contribution to the paper & Author(s) Signature \\
\hline 1 & Fatima Maroof & $\begin{array}{l}\text { Data collection, Data analysis, } \\
\text { Paper writing. }\end{array}$ & \\
\hline 2 & Tehmina Maqbool & $\begin{array}{l}\text { Data analysis \& Discussion } \\
\text { writing. }\end{array}$ & \\
\hline 3 & Hafiz Muhammad Irfan & Paper writing, Literature review. & \\
\hline 4 & Beenish Bashir Mughal & $\begin{array}{l}\text { Data analysis, Discussion } \\
\text { writing. }\end{array}$ & \\
\hline 5 & Aisha Anwar & $\begin{array}{l}\text { Data entry, Analysis, Paper } \\
\text { writing. }\end{array}$ & \\
\hline 6 & Nabeela Zia & $\begin{array}{l}\text { Data analysis, Literature } \\
\text { review. }\end{array}$ & Afor \\
\hline 7 & Muhammad Ahsan & Paper writing, Literature review. & Sear \\
\hline
\end{tabular}

